\title{
Political advertising — a research overview
}

\author{
Christina Holtz-Bacha \\ ORCID: 0000-0002-3836-5959
}

FRIEDRICH-ALEXANDER-UNIVERSITÄT ERLANGEN-NÜRNBERG, GERMANY

DOI: $10.19195 / 1899-5101.11 .2(21) .4$

\begin{abstract}
In the United States electoral advertising on television has always been the most important campaign tool. Even though social media are gaining relevance, a major share of the campaign budget still goes into TV advertising. In other parts of the world, electoral advertising on television is much more regulated, which may be the reason why this campaign tool has not reached the same relevance as in the U.S. This article provides a comprehensive overview of the different research perspectives and in particular discusses differences between the role of electoral advertising in the U.S. and other countries, which also pose a challenge for international comparisons.
\end{abstract}

KEYWORDS: Political advertising, elections, campaigns.

\section{INTRODUCTION}

While the importance of social media as campaign instruments is increasing, the 2016 presidential race in the United States once again confirmed the indispensability of electoral advertising on television. An estimated $\$ 845$ million were spent during the presidential campaign, including the nomination campaigns, which stands for a little over one million airings on broadcast television and national cable (Fowler, Ridout, \& Franz, 2016b, pp. 446-447).

In the U.S., electoral advertising went on television as soon as the new medium was available. It was the presidential election in 1952 when candidates used television for campaign advertising for the first time. Even though electoral advertising on television started in the 1950s in some other countries as well, television ads did not acquire the same relevance in election campaigns as in the U.S. In fact, the situation in the U.S. has remained unique in several aspects. Among the factors that account for the strong role of television ads in U.S. campaigns is first of all the absence of regulatory constraints as well as easy access to television. Right from the beginning, when broadcasting was introduced, the U.S. established a commercial system financed by advertising, which is hardly subject to any regulation. No difference was 
made between commercial and political advertising, in this way opening broadcasting for the purchase of advertising time by electoral candidates. Other than the candidates, interest groups are also allowed to purchase airtime in support of the candidates, thus adding to the enormous numbers of ads being broadcast during the campaign cycle. The Political Action Committees have become major players in electoral advertising, investing enormous amounts of money in support of their preferred candidate and usually also accounting for a high share of attack advertising.

There is also no restriction on the time when political advertising can be aired. The candidate-oriented electoral system further contributes to the importance of electoral advertising. Television has become the stage where fierce battles are fought out among the electoral contenders which are interested in the far reach of their campaign messages. The fact that advertising time must be paid for adds to the candidates' need to fill their war chests and dedicate much of their time to fundraising. The costs for advertising time also foster the tendency toward short and very short ads.

In contrast to the favorable conditions in the U.S., political advertising elsewhere is restricted in one way or the other, if permitted at all. One of the reasons for limiting political advertising on television or banning it completely is uncertainty as to whether it is appropriate to promote politics in the same way as commercial products and fear of the consequences for the image that the public holds of politics and political actors. This attitude is particularly apparent in countries with a tradition of public service broadcasting which rests on a social responsibility model of broadcasting. Similarly, politicians in the U.S. expressed reservations about audio-visual political advertising in the early days of television. In the 1952 presidential election campaign, the Democratic candidate Adlai Stevenson demonstrated his doubts about televised electoral advertising by stating: "I think the American people will be shocked by such contempt for their intelligence. This isn't Ivory Soap versus Palmolive" (Museum of the Moving Image, 2016). Four years later when Stevenson ran again, he had still not warmed to the new format but realized that modern election campaigning could not do without television.

Reservations about political advertising on television are also expressed in the term that is used for the promotional messages in different languages. Whereas it is common in the U.S. to speak of "ads", the format is called PEB, short for "party election broadcast", in the UK thus concealing the advertising character of the party broadcasts and at the same time hinting at the fact that broadcast time does not have to be paid for by the parties. The German and the French language use the term "(electoral) spot", which points to the brevity of the messages.

\section{REGULATION OF POLITICAL ADVERTISING ACROSS THE WORLD}

Regulation of political advertising can take various forms, ranging from a total ban of the spots to restrictions for their visual and verbal content (cf. Holtz-Bacha, 2017a, b). 
There are some countries, for instance Switzerland, Denmark, and Norway, that do not allow any political advertising on television. In the case of Norway for instance, the arguments for imposing the ban were "skepticism toward television as a powerful and manipulative medium" and "[w]orries (...) as to advertising having an adverse effect on democratic processes" (Iversen, 2016, p. 194).

Every so often, total bans of political advertising have been criticized on the grounds of infringement of freedom of expression (e.g., Jones, 2004; Rafter, 2011). In fact, the European Court of Human Rights (ECHR) had to deal with several complaints claiming a breach of Article 10 (Freedom of expression) of the European Convention on Human Rights by bans on political advertising (cf. Holtz-Bacha, 2014). The Court's decisions in the various cases were ambiguous but nevertheless confirmed the possibility of states imposing bans on political advertising on television (European Court of Human Rights, 2001, 2003, 2008, 2013). With reference to Article 10 of the European Convention on Human Rights, the Council of Europe (CoE) has also made political advertising an issue of its recommendations on free and fair elections for its $47 \mathrm{Member}$ States. For instance, in its "Code of good practice in electoral matters" the CoE's European Commission for Democracy through Law (the so-called Venice Commission) underlined the importance of equal opportunities for all electoral contenders and therefore promoted legal provisions to ensure minimum access to privately-owned audiovisual media also with respect to advertising as well as airtime on public or state-owned broadcasting (European Commission for Democracy..., 2002, pp. 7, 18).

The ECHR decisions reflect a difference between political and electoral advertising that can also be found in national legislation. Political advertising may be prohibited whereas electoral advertising is permitted. That means candidate and/or party advertising is possible for some weeks in preparation of elections, mostly during the so-called hot campaign phase and thus during the last four to six weeks before election day. Depending on the electoral system or the type of election, there may be differences as to whether advertising time is available for candidates and/ or for parties. Some countries also allow for supportive advertising by outside interest groups.

In those countries that have long been dominated by public service broadcasting, restrictions for political advertising are the rule. Many West European countries where public service broadcasting mostly held a monopoly until the 1980s control electoral advertising by way of free allocation of airtime on public television channels. When commercial broadcasting was introduced, these countries did not necessarily open the commercial channels up for political advertising. Thus, across the world, the legal conditions for the availability of airtime for electoral advertising are heterogeneous (Holtz-Bacha, 2017, pp. 6-7). Many countries oblige either public service or commercial television channels or both to allocate free airtime to candidates or parties. Assignment of time is done either on the principle of equality or as graded allocation according to the relevance of the contenders, however 
defined. The provision of advertising time at no cost also means that the number of time slots and length of the advertising is regulated and often very much restricted. If parties or candidates have the possibility to purchase time on television, the amount may also be capped either by the amount of money they can spend in a campaign or by time limitations.

In addition to formal restrictions there may be specifications for the visual and verbal content of the advertising. For instance, in some cases it is obligatory for the candidates to appear in person and take responsibility for the advertisement. Provisions for visual content may prohibit the use of national symbols or pictures of rivals. Regulation in some countries also tries to prevent negative advertising in the form of attacks on competitors. In any case, criminal law usually applies to preclude defamation, racism, or incitement to violence.

As the campaigners themselves are responsible for the production of the spots, the television stations are reduced to the role of transmitters. Where they are obliged to provide broadcast time, they will announce the spots or identify them visually as electoral advertising to make sure viewers know who is responsible and dissociate themselves from the contents. Typically, television stations do not have much leeway for refusing the broadcasting of the spots. Obligations to provide airtime for electoral advertising which may add up to several hours, and the risk of being associated with the contents make the spots unpopular with the broadcasters. However, they usually do not have any chance to influence respective regulations because of the strong interest of political actors in this marketing instrument that earns them a reach they cannot easily win with other campaign tools.

\section{CONTENT}

Due to the long tradition and the importance of advertising on television, the U.S. has the most extensive research on the content and effectiveness of the ads. Studies from other countries only receive international attention if they are published in English. All in all, there is also a lack of comparative research across countries. International comparisons of verbal and visual elements are particularly needed to identify generic formats and strategies used everywhere in contrast to national specificities that can be attributed to cultural differences.

There are several overviews summarizing the research on content aspects of electoral advertising in the U.S. (e.g., Fowler, Franz, \& Ridout, 2016a, ch. 3; Just \& Crigler, 2017; Kaid, 2004, 2006; West, 2014, ch. 4). Content analyses assess formal features and persuasive strategies employed in the visual and verbal parts of the ads. Reflecting the important role that negative advertising plays in the U.S., the analysis of this kind of campaigning received special attention in U.S. research (Belt, 2017; Just \& Crigler, 2017). More recently, negative campaigning has also become a research topic in other parts of the world (Nai \& Walter, 2015a; Walter \& Vlie- 
genthart, 2010). Over the years and with more women making it to the highest rungs on the political ladder, research has increasingly focused on gender in relation to political advertising. Studies have compared the verbal and visual strategies used by female and male candidates and how they present themselves in the spots (Bystrom, 2017).

However, the specificities of electoral advertising in the U.S. can only be established if the ads are brought into an international comparison. This would also be the approach to ascertain the model character of U.S. style advertising for campaigning elsewhere and determine whether it is justified to speak of an Americanization of campaigning worldwide.

Methodological problems make it difficult to compare electoral advertising across countries and cultures. Due to differences in length and style, it is a challenge to agree on common coding units, which would be necessary for systematic comparisons. The purchase of broadcast time in the U.S. is expensive, and therefore ads are mostly very short and often comprise only one presentational style (format). Thus, for instance, a negative spot is dominantly or completely negative and can be coded as such. In other countries and particularly where broadcast time is allocated, electoral spots are often much longer and encompass more than just one format (e.g., talking heads, montage, endorsement). In these cases, the presentational styles or formats lend themselves to serve as the coding unit (cf. Holtz-Bacha, 2000; Holtz-Bacha et al., 2014; Lessinger, 1997), which however makes it difficult to juxtapose findings from analyses that did not use the same coding unit.

Agreement on common categories is another challenge for international studies because the meaning and operationalization of concepts vary according to political culture. This problem can be exemplified by the employment of negativism in political advertising. Negative advertising is a must in U.S. campaigns. Candidates, and even more so the Political Action Committees, do not shy away from personal attacks on their rivals. Negative advertising is not equally acceptable in other countries and, if used at all, negativism is less aggressive than what we know from the U.S. and often rather implicit than explicit. So, negative advertising may be "a universal phenomenon" (Nai \& Walter, 2015b, p. 2) but definitions vary to a large extent (Nai \& Walter, 2015b, pp. 10-12).

Differences in the amount, intensity, and target of negativism also stem from a country's electoral system. In contrast to candidate-dominated systems, attacks targeting individual candidates are unusual in campaigns that are run by parties. This also touches upon the difficulty of comparing political advertising from presidential and parliamentary systems which comes along with the problem to decide whether differences in strategies are due to cultural factors or arise from the features of the political and electoral system.

The videostyle concept (Kaid \& Johnston, 2001), developed for the analysis of formal, verbal and nonverbal aspects of US candidate advertising, has been applied for the analysis of electoral spots in other countries as well (cf. Holtz-Bacha, Kaid, 
\& Johnston, 2000; Kaid \& Holtz-Bacha, 2006). Even though these studies used similar codebooks and their findings can therefore be brought into international comparisons, caution is recommended because of the methodological caveats mentioned above.

The European parliamentary elections provide for a unique opportunity for comparative research on political advertising. The large-scale study on the role of television in the first direct election to the European Parliament in 1979 (Blumler, 1983) also included the party broadcasts (Kelly \& Siune, 1983). It took some time until communication researchers once again seized the opportunity to launch a comparative project that included more than two EU member states. On occasion of the 2009 European election, Kaid et al. (2011) analyzed television advertising in ten countries and Holtz-Bacha et al. (2012) compared the spots broadcast during the campaign in France, Germany, Sweden, and the UK. In 2014, a team of researchers from all 28 member states applied the same codebook for analyzing the spots from the European election campaign (Holtz-Bacha, Novelli, \& Rafter, 2017). While studies like these are best suited to assess similarities and differences of spot advertising across countries and ascertain the impact of culture, the coding instrument will have to adapt to the lowest common denominator to allow for applicability in every country. Therefore, the findings of multi-country studies remain on the surface while necessarily losing the national subtleties.

\section{EFFECTS}

For campaigners, political advertising is all about effects. Ads are part of the campaign toolbox employed to garner votes and are thus designed to tell the electorate whom to vote for. The main interest of those who commission the electoral broadcasts therefore is effectiveness in the sense of getting people to vote and getting people to vote for them. However, in the same way as with commercial advertising, no direct persuasive effect can be expected for political advertising. If at all, influence on the voting decision is dependent on intervening factors as for instance sympathy for the candidate or issue involvement. Research on the reception and effects of electoral advertising therefore rarely focuses on changes in voting intention but rather addresses a broad spectrum of effects that may be relevant for the vote. Effects studies are usually based on experiments, surveys, qualitative interviews, or focus groups (Johnston, 2006; Kearney \& Banwart, 2017).

As other media content, electoral advertising can have attitudinal, affective, cognitive, or behavioral effects. Again, due to the fact that much of the research on political advertising was done in the U.S. (cf. Fowler, Franz, \& Ridout, 2016a, ch. 7; Kaid, 2004; Ridout \& Holland, 2017; West, 2014, ch. 6-7), a major part focused on candidate evaluations with the expectation that reinforcement or changes in sympathy for the candidate will have an impact on vote choice. In addition to the study of attitudinal effects, emotional strategies have recently gained increased attention 
(Brader, 2006; Marmor-Lavie \& Weimann, 2005). Because of the large amount of negative advertising, much of the research also concentrated on the effects of negativity and pointed to the risks of attack advertising (Fridkin \& Kenney, 2004; Garramone et al., 1990; Lau \& Pomper, 2004; Lau \& Rovner, 2009; Lau, Sigelman \& Rovner, 2007; Wattenberg \& Brians, 1999). Another line of research examined the effects of the ads' formal features such as length, format, color, or music (Donohue 1973; Kaid \& Sanders, 1978, Thorson et al., 1991).

Apart from intended effects, advertising can have effects that go beyond the electoral context and the actual target group. The television spots also reach children and adolescents who are not yet entitled to vote and may not yet have fullydeveloped and established political attitudes. The image of politics as conveyed in campaigns and in the spots may thus influence their picture of electoral races and the political process in general. The latter is also among the side-effects that electoral advertising may have on voters. The ads present a specific image of politics which may have consequences for the general attitudes towards and feelings about politics and politicians. Because the picture that people hold of the political system is supposed to influence political interest and participation, the effects of electoral advertising may go well beyond voting intention.

In an international context, effects research is even more difficult than the comparison of contents because the "stimulus" differs from one country to another. The stimulus in this case is campaign advertising and, as discussed above, very much rooted in the national (political) culture. This affects the design of spots and their verbal and visual contents as well as their general relevance in the election campaign. As is known from commercial advertising, there are marked differences in advertising styles and reception habits across cultures such as direct/less direct address of the viewers, display of the product, or presentation of arguments (de Mooij, 1998, pp. 228-231). More generally speaking, some cultures tend to adopt a soft sell approach in advertising, others to hard sell (e.g., Bradley, Hitchon, \& Thorson, 1994).

Therefore, even if the methodological conditions are similar, international comparisons of reception and effects of political advertising have to be done with caution. A pioneer study in this respect compared the reactions of voters to spots broadcast during the presidential election campaigns in France and in the U.S. in 1988 (Kaid, Gerstlé, \& Sanders, 1991) and found similar perceptions and emotions evoked by the advertising (Kaid, 1991). At the same time however, the study demonstrated the difficulties inherent in international collaboration and comparison of campaign communication.

Kaid has employed the same instruments to assess candidate sympathy and image changes by electoral spots in different countries. Even though findings cannot easily be compared, these studies show that the electoral spots affect the image of candidates in the short term (Kaid, 1999; Kaid \& Holtz-Bacha, 2006)

European Parliamentary elections again lend themselves to international comparison because at least the time and level of the election are constant but still the 
advertising is conceived and broadcast nationally. Maier et al. (2011) have used the setting of the 2009 European election to compare the effects of campaign communication in eleven EU member states.

\section{THEORETICAL BACKGROUND}

In spite of the high amount of research accumulated over more than six decades since the introduction of electoral advertising on television, much of it is practically oriented and in the interest of campaigners and the intended effects of the advertising. The study of electoral advertising and the choice of method often lack a theoretical background that takes the character of political advertising as persuasive communication into account. As part of the marketing mix, advertising is strategic communication with the purpose of selling a product or a service. In the same vein, political advertising is strategic communication employed by political actors with the purpose of promoting their product and garnering support for their decisions. In the case of elections, political advertising is done to win votes and gain or stay in power.

Similar to commercial advertising, political advertising reflects the cultural environment in which it is conceived and strives to persuade and seduce its audience. At the same time, as a representation of the political culture, electoral advertising contributes to the construction of political reality: "Advertising as a consciousness industry is involved in both creating culture and reflecting it" (Lester, 1994, p. 7). Thus, in addition to the immediate effect that campaigners are hoping for, that is to gain the hearts and minds of voters and finally their vote, electoral advertising needs to be regarded in a broader context. The advertising is a manifestation of political culture that also mirrors the changes of political culture over time (HoltzBacha, 2003). As such, the spots work beyond their target group and reach even those recipients who are not yet allowed to vote. They convey a picture of politics and political actors, which can intervene in their political socialization and influence attitudes, knowledge, and political behavior.

It is against this background that more international research is needed to allow for comparisons across countries. That should allow for the assessment of generic advertising strategies which are independent of their cultural environment. However, that also includes the requirement for better availability of studies from different countries because there is already much around, but all too often not accessible for language reasons, which is particularly the case in Europe with its many different languages.

\section{REFERENCES}

Belt, T. L. (2017). Negative advertising. In: C. Holtz-Bacha \& M. R. Just (eds.), Routledge Handbook of Political Advertising. New York: Routledge, pp. 49-60.

Blumler, J. G. (ed.) (1983). Communicating to Voters. Television in the First European Parliamentary Elections. London: Sage. 
Brader, T. (2006). Campaigning for the Hearts and Minds. How Emotional Appeals in Political Ads Work. Chicago: The University of Chicago Press.

Bystrom, D. (2017). Gender and political advertising: Content and effects. In: C. Holtz-Bacha \& M. R. Just (eds.), Routledge Handbook of Political Advertising. New York: Routledge, pp. 38-48.

Bradley, S., Hitchon, J., \& Thorson, E. (1994). Hard sell versus soft sell: A comparison of American and British advertising. In: B. G. Englis (ed.), Global and Multinational Advertising. Hillsdale: Lawrence Erlbaum, pp. 141-157.

De Mooij, M. (1998). Global Marketing and Advertising. Understanding Cultural Paradoxes. Thousand Oaks: Sage.

Donohue, T. R. (1973). Viewer perception of color and black-and-white paid political commercials. Journalism Quarterly, 50, pp. 660-665.

European Commission for Democracy through Law (2002). Code of good practice in electoral matters. Guidelines and explanatory report. [CDL-AD (2002) 23 rev]. Retrieved on 23 July, 2016 from http://www.venice.coe.int/webforms/documents/default.aspx?pdffile=CDL-AD(2002)023rev-e.

European Court of Human Rights (2001). Case of VgT Verein gegen Tierfabriken v. Switzerland. Judgment. Council of Europe. Retrieved on 3 July, 2016 from http://hudoc.echr.coe.int/eng?i=001-93265.

European Court of Human Rights (2003). Case of Murphy v. Ireland. Judgment. Retrieved on 3 July, 2016 from http://hudoc.echr.coe.int/eng?i=001-61207.

European Court of Human Rights (2008). Case of TV Vest AS \& Rogaland Pensjonistparti v. Norway. Judgment. Council of Europe. Retrieved on 3 July, 2016 from http://hudoc.echr.coe.int/ eng?i=001-90235.

European Court of Human Rights (2013). Case of Animal Defender International v. the United Kingdom. Judgment. Retrieved on 3 July, 2016 from http://hudoc.echr.coe.int/fre?i=001-119244.

Fowler, E. F., Franz, M. M., \& Ridout, T. N. (2016a). Political Advertising in the United States. Boulder: Westview Press.

Fowler, E. F., Ridout, T. N., \& Franz, M. M. (2016b). Political advertising in 2016: The presidential election as outlier? The Forum, 14(4), pp. 445-469.

Fridkin, K. L., \& Kenney, P. J. (2004). Do negative messages work? The impact of negativity on citizens' evaluations of candidates. American Politics Research, 32, pp. 570-605.

Garramone, G. M., Atkin, C. T., Pinkleton, B. E., \& Cole, R. T. (1990). Effects of negative political advertising on the political process. Journal of Broadcasting \& Electronic Media, 34, pp. 299-311.

Holtz-Bacha, C. (2001). Wahlwerbung als politische Kultur. Parteienspots im Fernsehen 1957-1998. Wiesbaden: Westdeutscher Verlag.

Holtz-Bacha, C. (2003). Political advertising during election campaigns. In: P. J. Maarek and G. Wolfsfeld (eds.), Political Communication in a New Era. A Cross-National Perspective. London: Routledge, pp. 95-116.

Holtz-Bacha, C. (2014). Political advertising in international comparison. In: H. Cheng (ed.), The Handbook of International Advertising Research. Malden: Wiley-Blackwell, pp. 554-574.

Holtz-Bacha, C. (2017a). Ample opportunities - mostly regulated: Political advertising across the world. In: C. Holtz-Bacha \& M. R. Just (eds.), Routledge Handbook of Political Advertising. New York: Routledge, pp. 3-12.

Holtz-Bacha, C. (2017b). Regulation of electoral advertising in Europe. In: C. Holtz-Bacha, E. Novelli, \& K. Rafter (eds.), Political Advertising in the 2014 European Parliament Elections. London: Palgrave Macmillan, pp. 27-37.

Holtz-Bacha, C., Johansson, B., Leidenberger, J., Maarek, P. J., \& Merkle, S. (2012). Advertising for Europe. TV ads during the 2009 European election campaign in four countries. Nordicom Review, 33, pp. 77-92.

Holtz-Bacha, C., Kaid, L. L., \& Johnston, A. (1994). Political television advertising in Western democracies: A comparison of campaign broadcasts in the U.S., Germany, and France. Political Communication, 11, pp. 67-80. 
Holtz-Bacha, C., Novelli, E., \& Rafter, K. (eds.). (2017). Political Advertising in the 2014 European Parliament Elections. London: Palgrave Macmillan.

Iversen, M. H. (2016). Breaking the ban. The use of televised political advertising in Norway. In: M. Edström, A. T. Kenyon \& E. M. Svensson (eds.), Blurring the Lines. Market-Driven and Democracy-Driven Freedom of Expression. Gothenburg: Nordicom, pp. 193-201.

Johnston, A. (2006). Methodologies for the study of political advertising. In: L. L. Kaid \& C. HoltzBacha (eds.), The Sage Handbook of Political Advertising. Thousand Oaks: Sage, pp. 15-34.

Jones, C. A. (2004). Regulating political advertising in the EU and USA: A human rights perspective. Journal of Public Affairs, 4(3), pp. 244-255.

Just, M. R., \& Crigler, A. (2017). The wild, wild West: Political advertising in the United States. In: C. Holtz-Bacha and M. R. Just (eds.), Routledge Handbook of Political Advertising. New York: Routledge, pp. 279-291.

Kaid, L. L. (1991). The effects of television broadcasts on perceptions of presidential candidates in the United States and France. In: L. L. Kaid, J. Gerstlé, and K. R. Sanders (eds.), Mediated Politics in Two Cultures. Presidential Campaigning in the United States and France. New York: Praeger, pp. 247-260.

Kaid, L. L. (1999). Comparing and contrasting the styles and effects of political advertising in European democracies. In: L. L. Kaid (ed.), Television and Politics in Evolving European Democracies. Commack: Nova Science Publishers, pp. 219-236.

Kaid, L. L. (2004). Political advertising. In: L. L. Kaid (ed.), Handbook of Political Communication Research. Mahwah: Lawrence Erlbaum, pp. 155-202.

Kaid, L. L. (2006). Political advertising in the United States. In: L. L. Kaid \& C. Holtz-Bacha (eds.), The Sage Handbook of Political Advertising. Thousand Oaks: Sage, pp. 37-61.

Kaid, L. L., Adam, S., Maier, M., Balzer, M., Berganza, R., Jalali, C., Negrine, R., Raycheva, L., Róka, J., Schuck, A. R. T., Stetka, V., \& de Vreese, C. (2011). Televised advertising in the 2009 European parliamentary elections. Comparing campaign strategies and videostyles. In: M. Maier, J. Strömbäck \& L. L. Kaid (eds.), Political Communication in European Parliamentary Elections. Farnham: Ashgate, pp. 91-110.

Kaid, L. L., \& Johnston, A. (2001). Videostyle in Presidential Campaigns. Style and Contents of Televised Political Advertising. Westport: Praeger.

Kaid, L. L., Gerstlé, J., \& Sanders, K. R. (eds.) (1991). Mediated Politics in Two Cultures. Presidential Campaigning in the United States And France. New York: Praeger.

Kaid, L. L., \& Holtz-Bacha, C. (2006). Television advertising and democratic systems around the world. A comparison of videostyle content and effects. In: L. L. Kaid \& C. Holtz-Bacha (eds.), The Sage Handbook of Political Advertising. Thousand Oaks: Sage, pp. 445-457.

Kaid, L. L., \& Sanders, K. R. (1978). Political television commercials. An experimental study of type and length. Communication Research, 5, pp. 57-70.

Kearney, M. W., \& Banwart, M. C. (2017). Methodological approaches. In: C. Holtz-Bacha \& M. R. Just (eds.), Routledge Handbook of Political Advertising. New York: Routledge, pp. 29-37.

Kelly, M., \& Siune, K. (1983). Television campaign structures. In: J. G. Blumler (ed.), Communicating to Voters. Television in the First European Parliamentary Elections. London: Sage, pp. 41-64.

Lau, R. R., \& Pomper, G. M. (2004). Negative Campaigning. An Analysis of U.S. Senate Elections. Lanham: Rowman \& Littlefield.

Lau, R. R., \& Rovner, I. B. (2009). Negative campaigning. Annual Review of Political Science, 12, pp. 285-306.

Lau, R. R., Sigelman, L., \& Rovner, I. B. (2007). The effects of negative political campaigns: A metaanalytic reassessment. Journal of Politics, 69, pp. 1176-1209.

Lessinger, E.M. (1997). Politische Information oder Stimmenfang? Eine explorative Studie zum Kommunikationsstil in Wahlwerbespots der Bundestagswahlen 1976 bis 1994 (unpublished Master's Thesis). Bochum: Ruhr-Universität Bochum. 
Lester, E. (1994). International advertising research and international communication theory. In: B. G. Englis (eds.), Global nd Multinational Advertising. Hillsdale: Lawrence Erlbaum, pp. 3-22. Maier, M., Adam, S., de Vreese, C., Schuck, A. R. T., Berganza, R., Stetka, V., Negrine, R., Jalali, C., Seeber, G. U. H., Raycheva, L., Róka, J., Dobek-Ostrowska, B., \& Grusell, M. (2011). Between integration and demarcation: Effects of Europeanized and national campaigns on voters in the 2009 European parliamentary elections. In: M. Maier, J. Strömbäck \& L. L. Kaid (eds.), Political Communication In European Parliamentary Elections. Farnham: Ashgate, pp. 233-256.

Marmor-Lavie, G., \& Weimann, G. (2005). Measuring emotional appeals in Israeli election campaigns. International Journal of Public Opinion Research, 18, pp. 318-339.

Museum of the moving image (2016). Presidential campaign commercials 1952-2016. 1952 Eisenhower vs. Stevenson. Retrieved on 12 October, 2017 from http://www.livingroomcandidate.org/ commercials/1952.

Nai, A., \& Walter, A. S. (eds.) (2015a). New Perspectives on Negative Campaigning. Why Attack Politics Matters. Colchester: ECPR Press.

Nai, A., \& Walter, A. S. (2015b). The war of words: The art of negative campaigning. In: A. Nai \& A. S. Walter (eds.), New Perspectives on Negative Campaigning. Why Attack Politics Matters. Colchester: ECPR Press, pp. 1-31.

Rafter, K. (2011). Hear no evil — see no evil: Political advertising in Ireland. Journal of Public Affairs, 11(2), pp. 93-99.

Ridout, T. N., \& Holland, J. L. (2017). The effects of political advertising. In: C. Holtz-Bacha \& M. R. Just (eds.), Routledge Handbook of Political Advertising. New York: Routledge, pp. 61-71.

Thorson, E., Christ, W. G., \& Claywood, C. (1991). Effects of issue-image strategies, attack and support appeals, music and visual content in political commercials. Journal of Broadcasting \& Electronic Media, 35, pp. 465-486.

Walter, A. S., \& Vliegenthart, R. (2010). Negative campaigning across different communication channels: Different ball games?. International Journal of Press Politics, 15, pp. 441-461.

Wattenberg, M. P., \& Brians, C. L. (1999). Negative campaign advertising: Demobilizer or mobilizer? American Political Science Review, 93, pp. 891-899.

West, D. M. (2014). Air Wars: Television Advertising and Social Media in Election Campaigns, 1952 $2012,6^{\text {th }}$ edition. Los Angeles: Sage. 